\title{
Recovery Role of Genistein in Modulating the Alterations in Some Haematological Parameters and Hepatic Antioxidant Enzymes in Gamma Irradiated Mice
}

\author{
S. S. Tawfik
}

Health Radiation Research Dept., National Centre for Radiation Research and Technology (NCRRT), 29 Nasr City,

Cairo, Egypt. E. mail; Samosoliman@Yahoo.com

\begin{abstract}
GENISTEIN; 4',5,7-trihydroxy-isoflavone $\left(\mathrm{C}_{15} \mathrm{H}_{10} \mathrm{O}_{5}\right)$ is an $\mathrm{J}_{\text {antioxidant nutrient, generally considered as a protective }}$ agent. The objective of this work is to study the radio recovery role of genistein in mitigating $\gamma$-rays induced injury to the liver and alterations in some haematological parameters of adult male mice. Genistein (150 mg/ kg body wt) was administrated to mice, once daily for 7 consecutive days before whole-body (4.5Gy) $\gamma$-rays-exposure then continued for 7 days after exposure..

The results showed that genistein significantly elevated liver catalase (CAT) and glutathione peroxidase (GPx) enzyme activities and decreased the malondialdehyde (MDA) level and myeloperoxidase (MPO) activity. Genistein treatment also, accelerated the recovery of circulating white blood cells (WBCs) and reticulocytes (RETs) counts throughout the experimental time. On the other hand, genistein failed in recovering the red blood cells (RBCs) count. Conclusion: Genistein has significant radio recovery task in $\gamma$-irradiated mice. Keywords: Genistein, oxidative-damage, radio recovery, $\gamma$-rays.
\end{abstract}

Radiotherapy has become a routine treatment for various types of malignancies. Several adverse side effects usually arise from radiotherapy including; decreased WBCs count and damaged immune function, which often prevent patients from finishing the treatment course. The application of antioxidant radio protectors to various human exposure situations has not been widespread although it is generally accepted that endogenous-antioxidants, such as cellular non-protein thiols and antioxidant-enzymes, provide some degree of protection (MirandaVilela et al., 2011). Exposure of mammals to ionising-radiation leads to development of complex, dose-dependant sequence of changes including different aspects of immunity (Bazyka, 2011) and injury to the lymphoid as well as haematopoietic systems which can cause septicaemia and death (Schaue et al., 2005). 
Exposure of mammals to ionising-radiation leads to development of complex, dose-dependant sequence of changes including different aspects of immunity (Bazyka, 2011) and injury to the lymphoid as well as haematopoietic systems which can cause septicaemia and death (Schaue et al., 2005). Currently, investigations focus on herbal and phytotherapeutic sources of chemo preventive agents because of the increasing use of complementary and alternative medicine among cancer patients and general public (Resnick and Avers, 2012).

Rusin et al. (2010) suggested that genistein as biological extract might be useful chemotherapeutic agent to inhibit the growth of cancer cells and accomplished that genistein shed some light for a new anti carcinogenic trial preventing various cancers on humans. In addition, genistein is able to reverse a diabetes established condition of oxidative stress and inflammation and ameliorates vascular dysfunction, thus suggesting its possible therapeutic use for inflammatory complications (Valsecchi et al., 2011). Other specific functions attributed to genistein are; increasing the numbers of white blood cells and enhancing immunological functions (Picmonova and Berger, 2010), improved cardiovascular function (vasodilataion and reduced platelet aggregation), antioxidant activity (increased oxygen radical-scavenging and decreased lipid oxidation), hypoglycaemic activity and stimulating of the pituitary-adrenocortical system (steroidal effect) (Ji et al., 2011). In addition, Neese et al. (2010) suggested that genistein modulates the immune system of aged mice. In addition, genistein protected the skin from oxidative damage induced by ultraviolet-rays (Wang 2010). More importantly, Li et al. (2010) found that oral administration of genistein stimulates haematopoiesis and increased survival in malignant animals. In addition, genistein stimulated haematopoiesis and increased survival in irradiated mice (Zhou and Tian, 2005). Moreover, in rats and mice, the micronuclei rates of genistein-treated mice after a single dose of irradiation with 7.5 Gy $\gamma$-rays were much lower than that of control animals (Wu et al., 2004).

Protecting normal host tissues from the lethal action of irradiation was of great clinical importance in radiation-medicine (Nair et al., 2001). During radiotherapy, ionizing-irradiation particles interact with biological system to induce excessive oxygen free radicals or reactive oxygen species (ROS), which Egypt. J. Rad. Sci. Applic., Vol. 24, No. 1 (2011) 
attack various cellular components including DNA, protein and membrane lipids, thereby leading to significant damage (Song et al., 2006). Thus, scavenging free radicals and inhibiting lipid peroxidation (LP) are likely key target activities for developing successful radioprotection strategies (Kunwar et al., 2010).

The objective of the present study was to investigated the role of genistein as a radio recovery agent against $\gamma$-radiations on some haematological parameters and the hepatic antioxidant enzyme activities in mice and the probable mechanisms by which genistein exerts its recovery role.

\section{Materials and Methods}

\section{Animals}

Thirty two male albino mice were purchased from the Laboratory Animal House of Institute of Ophthalmology, Giza, Egypt. The mice were 10-12 weeks weighed 20-24 g. They were given water ad-libitum, were fed on standard maintenance mouse food containing all the necessary nutritive elements and were adapted for one week prior to drug administration in the following atmosphere: $22 \pm 1^{\circ} \mathrm{C}$ and $60 \%$ relative humidity with $12 / 12$ light-dark cycle. The research protocols and all animal experiments followed the international guidelines and ethics.

\section{Genistein drug}

Genistein was obtained from Sigma-Aldrich, USA. It was prepared with $0.5 \mathrm{ml}$ of corn oil (mixed vigorously prior to use) and administrated orally by gavages at $150 \mathrm{mg} / \mathrm{kg}$ body wt once daily over 2 weeks (Calemine et al., 2003).

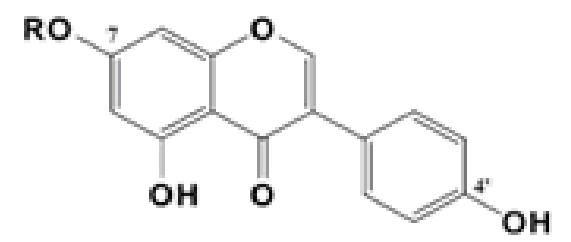

4',5,7-trihydroxy-(hydroxyphenyl) chromen-4-one

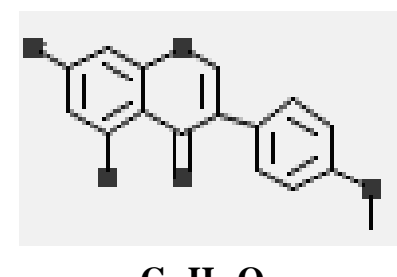

$\mathrm{C}_{15} \mathrm{H}_{10} \mathrm{O}_{5}$

Fig. 1. Genistein structure.

\section{Radiation facility}

The source of radiation was a gamma cell-40 for biological irradiation $\left({ }^{137}\right.$ Cesium) installed at the NCRRT, Nasr City, Cairo, Egypt. The radiation dose was sub lethal and sub acute single dosage of $4.5 \mathrm{~Gy} \gamma$-rays according protracted irradiation protocol of Song et al. (2006) at an exposure rate of $0.46 \mathrm{~Gy} / \mathrm{min}$.

Egypt. J. Rad. Sci. Applic., Vol. 24, No. 1 (2011) 


\section{Intervention method}

Randomised mice divided into 4 groups: Control group, treated orally with daily $0.5 \mathrm{ml}$ corn oil for 2 weeks. Genisten, treated with their respective genistein doses for 2 weeks. Irradiated (IRR), treated orally with daily $0.5 \mathrm{ml}$ corn oil for 7 days before- as well as after-exposure to $\gamma$-radiation. Protracted (Gen+ IRR+ Gen), treated with their respective genistein doses for 7 consecutive days before being exposed to $\gamma$-rays and thereafter irradiation, for another 7 days. The livers were dissected, washed with ice-cold saline and stored at $-40{ }^{\circ} \mathrm{C}$ until assayed.

\section{Assessment of some haematological parameters; WBC, RET and RBCs counts}

Blood was collected from the tail caudal veins into heparinised tubes before sacrifice. Total white blood cells (WBCs) count and red blood cells (RBCs) count were measured by automated blood counter (coulter model T450x, Contronics Co., USA). In specially stained smears (New Methylene Blue), the RETs number was estimated per $10^{3} \mathrm{RBCs}$ and was then calculated per litre.

\section{Evaluations of lipid-peroxidation and hepatic antioxidant enzyme activities}

$10 \%$ liver tissue homogenate was prepared in $0.9 \%$ ice-cold saline and the homogenized tissues were centrifuged at $6000 \mathrm{xg}$ at $4^{\circ} \mathrm{C}$ for $30 \mathrm{~min}$. The supernatant was collected to estimate malondialdehyde (MDA) level by the thiobarbituric acid substances (TBARS) as described by Devasagayam and Tarachand (1987) and the relative antioxidant enzyme activities of MPO, CAT and GPx were estimated following methods described by Hillegas et al. (1990), Sinha (1972) and Rotruck et al. (1973), respectively. Protein assays in the samples were determined by the method of Bradford (1976).

\section{Statistical analysis}

Statistical analysis was performed using student-paired $t$-test described by Sendecor and Cochran (1980), with $P<0.05$ considered statistically significant.

\section{Results}

Total WBCs and RETs counts in IRR groups decreased significantly compared with those of the control mouse groups. Seven days after $\gamma$-irradiation, the WBCs and RETs counts of the protracted groups (Gen+ IRR+ Gen) were elevated to $177 \%$ and $214 \%$, respectively. On the other hand, the RBCs alteration in genisten, IRR and protracted groups were not significantly different, Table 1.

Egypt. J. Rad. Sci. Applic., Vol. 24, No. 1 (2011) 
TABLE 1. Effect of genisten pre- and post-treatment on WBCs, RETs and RBCs of $\gamma$-irradiated $(4.5 \mathrm{~Gy}$ ) male mice.

\begin{tabular}{|c|c|c|c|c|}
\hline & Control & Genisten & IRR & Gen+ IRR+ Gen \\
\hline $\begin{array}{r}\text { WBCs } \\
\begin{aligned}(x & \left.10^{3} / \mathrm{ml}\right) \\
\% & \text { Change }\end{aligned} \\
\end{array}$ & $4.55 \pm 0.93$ & $\begin{array}{c}4.72 \pm 0.13 \\
4 \%\end{array}$ & $\begin{array}{c}0.92 \pm 0.28^{\mathbf{a}, \mathbf{b}} \\
-80 \%\end{array}$ & $\begin{array}{c}2.55 \pm 1.22^{\mathrm{c}} \\
177 \%\end{array}$ \\
\hline 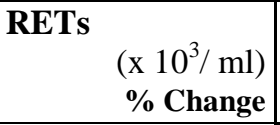 & $11.10 \pm 2.04$ & $\begin{array}{c}10.80 \pm 2.45 \\
-3 \%\end{array}$ & $\begin{array}{c}3.34 \pm 1.21^{\mathbf{a}, \mathbf{b}} \\
-70 \%\end{array}$ & $\begin{array}{c}10.50 \pm 3.35^{\mathbf{c}} \\
214 \%\end{array}$ \\
\hline 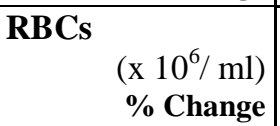 & $8.29 \pm 1.13$ & $\begin{array}{c}8.66 \pm 0.15 \\
4 \%\end{array}$ & $\begin{array}{c}7.13 \pm 0.77 \\
-14 \% \\
\end{array}$ & $\begin{array}{c}7.91 \pm 0.60 \\
11 \% \\
\end{array}$ \\
\hline
\end{tabular}

Data presented as $\mathrm{M} \pm \mathrm{SD}$ obtained from 8-mice per group.

$\mathrm{IRR}=$ irradiation. Gen+ IRR+ Gen= genistein+ Irradiation+ genistein.

$\%$ Change of genistein- and IRR-group versus control group.

$\%$ Change of protracted (Gen+ IRR+ Gen)-group versus IRR group.

a, Significantly different versus control group.

b, Significantly different versus genistein-treated group.

c, Significantly different versus IRR-group.

Liver MDA and MPO levels of IRR-group significantly increased comparing with their respective levels in control group by $41 \%$ and $48 \%$, respectively. Whereas, a significant decline in protracted group was recorded as compared with those in the IRR-group by $31 \%$ and $33 \%$, respectively, Table 2 .

TABLE 2. Effect of of genisten pre- and post-treatment on liver-prooxidant (MDA) and liver- antioxidant enzyme activities (MPO, CAT and GPx) of $\gamma$-irradiated (4.5 Gy) male mice.

\begin{tabular}{|c|c|c|c|c|}
\hline & Control & Genisten & IRR & Gen+ IRR+ Gen \\
\hline $\begin{array}{r}\text { MDA (TBARS) } \\
\text { nmol/ ml protein } \\
\% \text { Change }\end{array}$ & $2.17 \pm 0.511$ & $\begin{array}{c}2.14 \pm 0.521 \\
-1 \%\end{array}$ & $\begin{array}{c}3.07 \pm 0.515^{\mathbf{a}, \mathbf{b}} \\
41 \%\end{array}$ & $\begin{array}{c}2.13 \pm 0.243^{\mathrm{c}} \\
-31 \%\end{array}$ \\
\hline \begin{tabular}{|l|} 
MPO \\
\\
U/ g protein \\
$\%$ Change \\
\end{tabular} & $0.132 \pm 0.028$ & $\begin{array}{c}0.130 \pm 0.034 \\
-2 \% \\
\end{array}$ & $\begin{array}{c}0.195 \pm 0.052^{\mathbf{a}, \mathbf{b}} \\
48 \% \\
\end{array}$ & $\begin{array}{c}0.131 \pm 0.014^{\mathrm{c}} \\
-33 \%\end{array}$ \\
\hline $\begin{array}{r}\text { CAT } \\
\text { NU/ mg protein } \\
\text { \% Change }\end{array}$ & $3.25 \pm 0.429$ & $\begin{array}{c}3.35 \pm 0.344 \\
3 \%\end{array}$ & $\begin{array}{c}2.34 \pm 0.257^{\mathbf{a}, \mathbf{b}} \\
-28 \%\end{array}$ & $\begin{array}{c}3.34 \pm 0.462^{\mathrm{c}} \\
43 \%\end{array}$ \\
\hline $\begin{array}{r}\text { GPx } \\
\text { U/ mg protein } \\
\% \text { Change } \\
\end{array}$ & $7.64 \pm 0.836$ & $\begin{array}{c}7.72 \pm 0.915 \\
1 \% \\
\end{array}$ & $\begin{array}{c}6.26 \pm 0.731^{a, b} \\
-18 \\
\end{array}$ & $\begin{array}{c}8.20 \pm 1.021^{\mathrm{c}} \\
31 \%\end{array}$ \\
\hline
\end{tabular}

The legend as in Table 1.

Egypt. J. Rad. Sci. Applic., Vol. 24, No. 1 (2011) 
Liver CAT and GPx activities in IRR-group decreased significantly, comparing with their activities in control group by $28 \%$ and $18 \%$, respectively. Administration of genistein before- and after-irradiation significantly enhanced the activity of these two enzymes by $43 \%$ and $31 \%$, respectively as compared to those of the IRR-group, Table 2.

\section{Discussion}

It is generally agreed that radiation death in animal is due to impairment of bone marrow haematopoietic function and that the leucopenia, erythropenia and thrombocytopenia which ultimately developed to infection, haemorrhage and death. Accordingly, peripheral blood cell counts were used as indicators of bone marrow function in order to assess the role of radio recovery on normal tissues and cells, which is critical for animal health. Furthermore, chemotherapy- and/ or radiotherapy -induced damage to the blood circulatory system of cancer patients persists as a difficult clinical problem (Garssen et al., 2010).

The radio recovery effect of genistein administration before- and afterirradiation was investigated in adult male mice. At the tested dose $(150 \mathrm{mg} / \mathrm{kg}$ body wt), there was no adverse effect, compared with control.

In the present study, irradiation causes sever decline in both WBCs and RETs counts. RETs decline following irradiation reflects the early damage of the bone marrow haematopoietic function (Tran et al., 2011). The results showed that genistein stimulated the elevation of WBCs and RETs counts after irradiation, suggesting that genistein could attenuate irradiation-induced damage to the blood haemograms. In addition, rapidly dividing cells of the blood system, especially leucocytes and erythrocytes are highly prone to irradiationinduced damage because ROS impacts the blood system and decreases its cellular components including RETs, considerably. The cell membranes of circulating WBCs and RETs have very high phospholipid content, rendering them susceptible to oxidative damage induced during irradiation. Genistein has been reported to induce proliferation bone marrow cells as well as the release of haematopoietic growth factors, which suggested that it might have a protective effect on irradiated-mice (Liang et al., 2005 and Para et al., 2009). Other investigators supported the present data; Wu et al. (2004) reported that blood Egypt. J. Rad. Sci. Applic., Vol. 24, No. 1 (2011) 
cell counts of genistein-protected mice after single dose of $\gamma$-irradiation (7.5 Gy) were higher than those of the control group. Specific functions attributed to genistein are increasing the numbers of WBCs and enhancing immunological functions (Singh et al., 2009). In addition, Ashry and Hussein (2006) concluded that genistein pre-treatment may be a useful agent to reduce the time necessary for reconstituting haematopoietic cells after irradiation and may hold promise for use as a future radio protector. On the other hand, genistein failed in recovering RBCs count in irradiated mice. In contrary, Ashry (2009) found that a combination of iadzein and genistein treatment before and through irradiation accelerated the recovery of circulating RBCs in rats. Zhou and Tian (2005) observed that genistein stimulated recovery of nucleated peripheral blood cells in irradiated mice.

Irradiation at the dose level of $4.5 \mathrm{~Gy}$ resulted in marked oxidative-stress presented by the significant increase in MDA level and MPO activity. These results are in agreement with recent studies (Gauter-Fleckenstein et al., 2010 and Vicentini et al., 2011). Genistein significantly decreased MDA levels in liver tissues are accordance with (Kim et al., 2009). Accordingly, the author suggests that the anti-lipoperoxidative effect of genistein may be explained by its direct free radical scavenger property.

Generalized tissue-inflammation is present in injured-organs by irradiation in the post-irradiation period (Ponemone et al., 2010). Neutrophils are likely the source of reactive-oxygen metabolites as a result of the systemic inflammatory reaction to a local irradiation-insult (Chen et al., 2005). MPO plays an important role in the production of oxidants by neutrophils, which are a potential source of ROS and are considered to be the major effectors' cells in remote organ-damage (Dib et al., 2002). In this study, the tissue-associated MPO activity, which is an index of neutrophil-infiltration, was increased in liver after irradiation-exposure.

According to present study, treating mice with genistein attenuated the increase in the tissue levels of MPO and MDA caused by radiation-injury. In addition, it has been suggested that genistein exhibited antioxidant properties by blocking the production of ROS (Ma et al., 2010). Moreover, mitigation of oxidative stress, or excessive free-radical damage, may be especially relevant. 
Genistein as antioxidant protected the outer membranes of cells, particularly nerve and immune cells probably via activation of antioxidant enzyme gene transcription (Ma et al., 2010).

Tawfik et al. (2006) concluded that excessive ROS produced during irradiation-exposure could cause tissue injury through LP and alteration of antioxidant enzyme activities. In addition, Song et al. (2006) results showed that genistein increased the gene-expression levels of the CAT and GPx antioxidantenzymes after irradiation.

The results showed that genistein significantly elevated CAT and GPx activities. The author suggests that genistein possesses potential antioxidative activity in mitigating oxidative-stress resulting from irradiation in mice. In consistence with the present concept, Liu et al. (2011) reported that antioxidants have been proposed as therapeutic agents, as well as drug co-adjuvant to counteract liver-damage.

Treatment with genistein protected mice from the lethal effects of ionisingradiation (Para et al., 2009) and was more effective than when given immediately after or at various times after irradiation (Song et al., 2003). It acted through inhibition of anti-inflammatory pathways (Singh et al., 2009) and had cyto-protective activity (Sun et al., 1991). In addition, it has been reported to have immune modulator effects and acceleration of metabolism and enhanced bone mineralisation and bone metabolism (Branca, 2003) and enhance physical performance (Liang et al., 2005). In addition, it markedly inhibited LP and markedly opposed radical processes and thus reduced the radiation-damage (Kumar et al., 2003). In mouse models, it enhanced the activity of macrophages and caused immune modulation (Wang et al., 2003) and provided protection against acute radiation injury (Landauer et al., 2003). In farm animals, genistein had adjuvant effects in stimulating antibody response (Hu et al., 2003). In mink animals, genistein help in reproductive organ development (Ryoekkynen et al., 2005).

\section{Conclusion}

The results provided encouraging clues that genistein could serve as a potential radio-recovering agent in mice through inhibition of free radical Egypt. J. Rad. Sci. Applic., Vol. 24, No. 1 (2011) 
generation or their intensified scavenging, membrane repair, replenishment of dead haemogram and other cells by enhancing their recovery.

\section{Recommendation}

Further evaluation by using this model will provide an effective goal for a new strategy of radiotherapy and further studies are necessary to determine the mechanisms of its radio protective and radio recovery actions.

\section{References}

Ashry, O. M. (2009) Protective effect of combined administration of isoflavones genistein and daidzein against irradiation-induced damage in female rats. Egypt. J. Rad. Sci. Applic., 22, 167.

Ashry, O. M. and Hussein, E. M. (2006) Radioprotective potency of ginseng on some haematopoeitic and physiological parameters in irradiated rats. Egypt. J. Rad. Sci. Applic., 20, 39.

Bazyka, D. (2011) Immunological effects of the Chernobyl accident. Encyclopedia of Environmental Health, Research Center for Radiation Medicine, Kyiv, Ukraine, pp. 155-164.

Bradford, M. M. (1976) A rapid and sensitive method for the quantitation of microgram quantities of protein utilizing the principle of protein-dye binding. Anal. Biochem., 72, 248.

Branca, F. (2003) Dietary phyto-oestrogens and bone health. Proc. Nutr. Soc., 62, 877.

Calemine, Ji., Zalenka, J., Karpuzoglu-Sahin, E., Ward, D. L., Lengi, A., Ahmed, S. A. (2003) The immune system of geriatric mice is modulated by estrogenic endocrine disruptors (diethylstilbestrol, alpha-zearalanol, and genistein): Effects on interferon-gamma. Toxicol., 194, 115.

Chen, M. F., Chen, W. C., Wu, C. T. and Chen Y. J. (2004) Cell killing and radiosensitization by caffeic acid phenethyl ester (CAPE) in lung cancer cells. Rad. Res., 45, 253.

Devasagayam, T. P. and Tarachand, U. (1987) Decreased lipid peroxidation in the rat kidney during gestation. Biochem. Biophys. Res.Commun., 145, 134.

Dib, M., Zhao, X., Wang, X. D., Andersson, R. (2002) Role of mast cells in the development of pancreatitis-induced multiple organ dysfunction. Br. J. Surg., 89, 172.

Garssen, B., Boomsma, M. and Beelen, R. (2010) Psychological factors in immunomodulation induced by cancer surgery: A review. Biolog. Psychol., 85,1 .

Egypt. J. Rad. Sci. Applic., Vol. 24, No. 1 (2011) 
Gauter-Fleckenstein, B., Fleckenstein, K., Owzar, K., Jiang, C., Rebouças, J., Batinic-Haberle, I. and Vujaskovic, Z. (2010) Early and late administration of MnTE-2-PyP ${ }^{5+}$ in mitigation and treatment of $\gamma$-radiation-induced lung damage. Free Radical Biology and Medicine, 48, 1034.

Hillegas, L. M., Griswold, D. E., Brickson, B. and Albrightson-Winslow, C. (1990) Assesment of myeloperoxidase activity in whole rat kidney. J. Pharmacol. Methods, 24, 285.

Hu, S., Concha, C., Lin, F. and Persson Waller, K. (2003) Adjuvant effects of gensing extracts on the immune responses to immunization against Staphylococcus aureus in dairy cattle. Vet. Immunol. Immunopathol., 91, 29.

Ji, G., Yang, Q., Hao, J., Guo, L., Chen, X., Hu, J., Leng, L. and Jiang, Z. (2011) Anti-inflammatory effect of genistein on non-alcoholic steatohepatitis rats induced by high fat diet and its potential mechanisms. Int. Immunopharmacol., 134.

Kim, J., Jin, Y., Kim, Y., Rhie, S., Kim, H., Seo, H., Lee, J., Ha, Y. and Chang, K. (2009) Daidzein administration in vivo reduces myocardial injury in a rat ischemia/reperfusion model by inhibiting NF-kB activation. Life Sci., 84, 227.

Kumar, M., Sharma, M., Saxena, P. and Kumar, A. (2003) Radioprotective effect of Panax ginseng on the phosphatases and lipid peroxidation level in the testes of swiss albino mice. Biol. Pharm. Bull., 26, 308.

Kunwar, A., Bansal, P., Kumar, S., Bag, P., Paul, P., Reddy, N., Kumbhare, L., Jain, V., Chaubey, R., Unnikrishnan, M. and Priyadarsini, K. (2010) In vivo radioprotection studies of 3,3'-diselenodipropionic acid, a selenocystine derivative. Free Rad. Biol. Med., 48, 399.

Landauer, M. R., Srinivasan, V. and Seed, T. M. (2003) Genistein treatment protects mice from ionizing radiation injury. Appl. Toxicol., 23, 379.

Li, W., Frame, L., Hirsch, S. and Cobos, E. (2010) Genistein and hematological malignancies.Cancer Lett., 296, 1.

Liang, M. T., Podolka, T. D. and Chuang, W. J. (2005) Panax ginseng supplementation enhance physical performance during endurance exercise. $J$ Strength Cond. Res., 19, 108.

Liu, Q., Kong, B., Li, G., Liu, N. and Xia, X. (2011) Hepatoprotective and antioxidant effects of porcine plasma protein hydrolysates on carbon tetrachlorideinduced liver damage in rats. Food Chem. Toxicol., 49, 1316.

Ma, W., Yuan, L., Yu, H., Ding, B., Xi, Y., Feng, J. and Xiao, R. (2010) Genistein as a neuroprotective antioxidant attenuates redox imbalance induced by $\beta$ amyloid peptides 25-35 in PC12 cells. Int. J. Developm. Neurosci., 28, 289.

Egypt. J. Rad. Sci. Applic., Vol. 24, No. 1 (2011) 
Miranda-Vilela, A., Portilho, F., de Araujo, V., Estevanato, L., Mezzomo, B., Santos, M. and Lacava, Z. (2011) The protective effects of nutritional antioxidant therapy on Ehrlich solid tumor-bearing mice depend on the type of antioxidant therapy chosen: histology, genotoxicity and hematology evaluations. J. Nutrit. Biochem., 22, 1091.

Nair, C. K., Parida, D. K. and Nomura, T. (2001) Radioprotectors in radiotherapy. Rad. Res., 42, 21.

Neese, S., Wang, V., Doerge, D., Woodling, K., Andrade, J., Helferich, W., Korol, D., Schantz, S. (2010) Impact of dietary genistein and aging on executive function in rats. Neurotoxicol. Teratol., 32, 200.

Para, A., Bezjak, A., Yeung, I., Dyk, J. and Hill, R. (2009) Effects of genistein following fractionated lung irradiation in mice. Radiotherapy and Oncology, 92, 500 .

Picmonova, V. and Berger, J. (2010) Genistein effects on haematoimmune cells in a newly developed alternative toxicological model. Experim. Toxicol. Pathol., Epub ahead of print.

Ponemone, V., Fayad, R., Gove, M. E., Pini, M. and Fantuzz, G. (2010) Effect of adiponectin deficiency on intestinal damage and hematopoietic responses of mice exposed to gamma radiation. Mutat. Res., 690, 102.

Resnick, B. and Avers, D. (2012) Motivation and patient education: Implications for Physical Therapist Practice. Geriatric Physical Therapy ( ${ }^{3} \mathrm{rd}$ ed.), Mosby, Inc., USA, pp. 183-206.

Rotruck, J. T., Pope, A. L., Ganther, H. E., Swanson, A. B., Hafeman, D. G. and Hoekstra, W. G. (1973) Selenium: biochemical role as a component of glutathione peroxidase. Sci., 179, 588.

Rusin, A., Krawczyk, Z., Grynkiewicz, G., Gogler, A., Zawisza-Puchalka, J. and Szeja, W. (2010) Synthetic derivatives of genistein, their properties and possible applications. Acta Biochim. Pol., 57, 23.

Ryoekkynen, A., Nieminen, P., Mustonen, A. M., Pyykoenen, T., Asikainen, J., Haenninen, S., Mononen, J. and Kukkonen, J. (2005) Phytoestrogens alter the reproductive organ development in the mink (Mustela viso). Toxicol. Appl. Pharmacol., 202, 132.

Schaue, D., Jahns, J., Hildebrandt, G. and Trott, F. (2005) Radiation treatment of acute inflammation in mice. Int. J. Rad. Biol., 81, 657.

Singh, V., Grace, M., Parekh, V., Whitnall, M. and Landauer, M. (2009) Effects of genistein administration on cytokine induction in whole-body gamma irradiated mice. Int. Immunopharmacol., 9, 1401.

Sinha, A. K. (1972) Colorimetric assay of catalase. Anal. Biochem., 47, 389.

Egypt. J. Rad. Sci. Applic., Vol. 24, No. 1 (2011) 
Snedecor, W. G. and Cochran, G. W. (1980) "Statistical methods". $7^{\text {th }}$ ed., Iowa State Univ. Press, Ames, Iowa.

Song, J.., Han, K., Bae, G., Lim, S., Son, J., Jung, S., Yi, Y. and Yun, S. (2003) Radioprotective effects of ginsan, an immunomodulator. Rad. Res., 159, 768.

Song, L. H., Yan, H. L. and Cai, D. L. (2006) Protective effects of Soybean Isoflavone against Gamma-irradiation induced damage in mice. Rad. Res., 47, 157.

Sun, X., Matsumoto, T., Kiyohara, H., Hirano, M. and Yamada, H. (1991) Cytoprotective activities of pectic polysaccharides from the root of Panax ginsing. J. Ethnopharmacol., 31, 101.

Tawfik, S. S., Abbady, M. I., Zahran, A. M. and Abouelalla, A. M. K. (2006) Therapeutic efficacy attained with thyme essential oil supplementation throughout $\gamma$-irradiated rats. Egypt. Rad. Sci., Applic., 19, 1.

Tran, S., Sumita, Y., and halili, S. (2011) Bone marrow-derived cells: A potential approach for the treatment of xerostomia. Int. J. Biochem. Cell Biol., 43, 5.

Valsecchi, A., Franchi, S., Panerai, A., Rossi, A., Sacerdote, P. and Colleoni, M. (2011) The soy isoflavone genistein reverses oxidative and inflammatory state, neuropathic pain, neurotrophic and vasculature deficits in diabetes mouse model. Eur. J. Pharmacol., 650, 694.

Vicentini, F., He, T., Shao, Y., Fonseca, M., Jr., W., Fisher, G. and Xu, Y. (2011) Quercetin inhibits UV irradiation-induced inflammatory cytokine production in primary human keratinocytes by suppressing NF-KB pathway. $J$. Dermatolog. Sci., 61, 162.

Wang, H., Actor, J. K., Indrigo, J., Olsen, M. and Dasgupta, A. (2003) Asian and Siberian ginseng as a potential modulator of immune function: an in vitro cytokine study using mouse macrophages. Clin. Chim. Acta., 327, 123.

Wang, Y., Wu, W., Chen, H. and Fang, H. (2010) Genistein protects against UVBinduced senescence-like characteristics in human dermal fibroblast by p66Shc down-regulation. J. Dermatol. Sci., 58, 19.

Wu, J., Jin, H., Xu, Z., Wang X., Nan, W. and Li, P. (2004) The experimental study on radioprotective effect of genistein. Chinese J. Radiol. Health, 13, 170.

Zhou, Y. and Tian, M. M. (2005) Genistein stimulated hematopoiesis and increase survival in irradiated mice. J. Rad. Res., 46, 425.

(Received: 14/04/2011;

accepted: 26/05/2011)

Egypt. J. Rad. Sci. Applic., Vol. 24, No. 1 (2011) 
الاور العلاجي للجينستين في تعديل تغيرات بعض المعايير

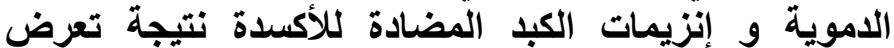

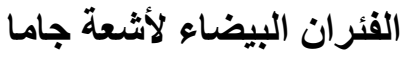

سامتح سليمان توفيق

قسم البحوث الصحية الإشعاعية ، المركز القومي لبحوث وتكنولوجيا الإشعاع ، ص. ب: 9 Y مدينة نصر ، مصر.

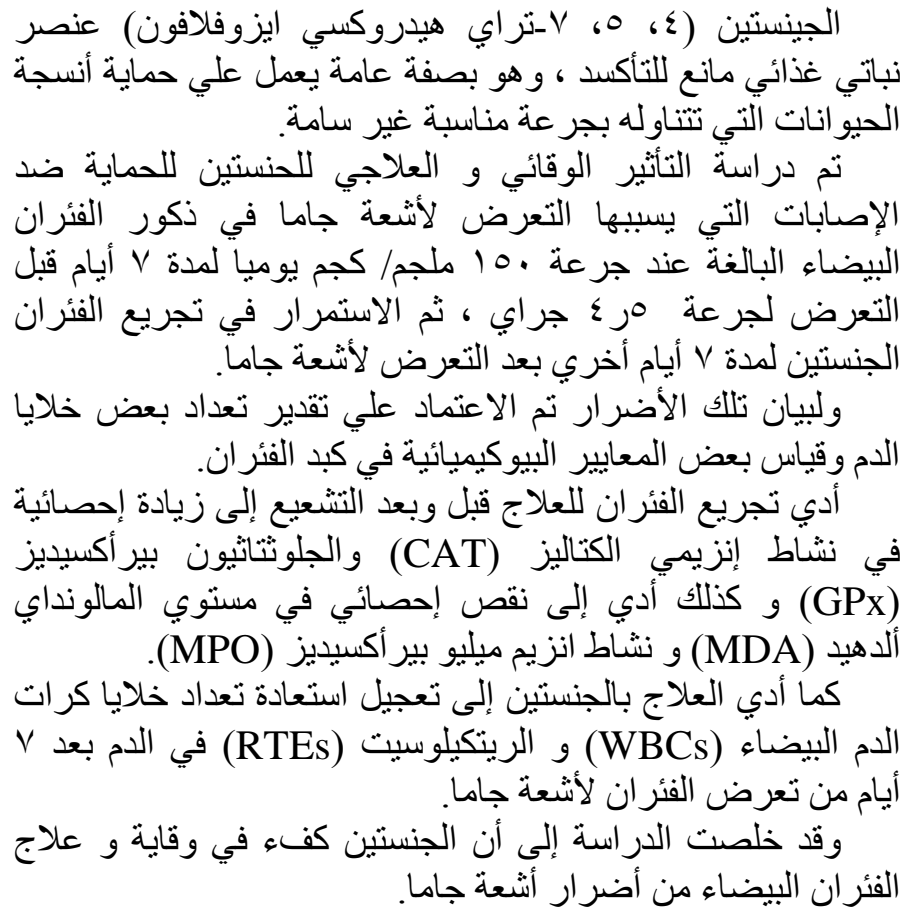

Egypt. J. Rad. Sci. Applic., Vol. 24, No. 1 (2011) 